
\title{
28 Resarch Square \\ Phytoremediation of Heavy Metals by Typha angustifolia in Hokersar Wetland of Kashmir
}

Syed Shakeel Ahmad ( $\sim$ ssahmad900@gmail.com )

University of Kashmir

\section{Zafar Reshi}

University of Kashmir

Manzoor A Shah

University of Kashmir

\section{Roshan Ara}

University of Kashmir

Irfan Rashid

University of Kashmir

\section{Research Article}

Keywords: Wetland, macrophytes, heavy metals sequestration, Typha angustata, Kashmir Himalaya

Posted Date: July 13th, 2021

DOl: https://doi.org/10.21203/rs.3.rs-687636/v1

License: (c) (1) This work is licensed under a Creative Commons Attribution 4.0 International License. Read Full License 


\section{Abstract}

Remediation of heavy metals by macrophytes in wetlands is gaining importance, particularly in the wetlands and game reserves of international importance. Hokersar wetland, a Ramsar site, is a game reserve of international importance and is facing anthropogenic disturbances over the years. Keeping in view deleterious effect of heavy metals on all the facets of contaminated ecosystems need for removal of these contaminants has received lot of attention in the recent past. It is in this backdrop, heavy metal sequestration by Typha angustata, one of the common and abundant species growing in the wetland, was explored. The study was aimed to assess sequestration of heavy metals, such as $\mathrm{Al}, \mathrm{Cd}, \mathrm{Co}, \mathrm{Cr}, \mathrm{Cu}$, $\mathrm{Fe}, \mathrm{Mn}, \mathrm{Ni}, \mathrm{Pb}$ and $\mathrm{Zn}$ by $\mathrm{T}$. angustata in the Hokersar wetland. The EF for all the investigated heavy metals was greater than one and TF of $T$. angustata was greater than one for $\mathrm{Zn}, \mathrm{Cr}$ and $\mathrm{Pb}$ thereby making the species a hyper-accumulator for these elements. In conclusion, it can be stated that $T$. angustata, being a hyperaccumulator of $\mathrm{Zn}, \mathrm{Cr}$ and $\mathrm{Pb}$ and accumulator for $\mathrm{Fe}, \mathrm{Mn}, \mathrm{Al}, \mathrm{Co}, \mathrm{Cu}, \mathrm{Ni}$ and $\mathrm{Cd}$ can be exploited for heavy metal sequestration in the wetland system.

\section{Introduction}

Heavy metals - metals with density of $5 \mathrm{~g} / \mathrm{cc}$ (Nies 1999) - are an important category of pollutants that have major detrimental impacts on both human health (Buruiana et al. 2015) and the health of terrestrial and aquatic communities and ecosystems (Chopalla et al. 2014; Sánchez 2008). Phytoremediation of metals is a cost-effective "green" technology based on the use of specially selected metal-accumulating plants to remove toxic metals from soils and water. This environmentally friendly and low cost technology can be used to decontaminate soils, water and sediments containing organic compounds and/or metals (Gerhardt et al. 2009; Kramer 2010). Several plant species have been used for phytoremediation of heavy metals from contaminated water and soil (Chandra and Yadav 2011; Hu et al. 2010; Mishra et al. 2007; Rai et al. 1995; Rai 2008; Sharma and Gaur 1995; Samecka-Cymerman and Kampers 2007; Szymanowska et al. 1999; Vardanyan and Ingole 2006; Zhang et al. 2009). Wetland plants, however, vary greatly in their degree of metal uptake (Qian et al. 1999; Deng et al. 2004) and species that hyper accumulate metals have a tremendous potential for application in metal remediation.

Exposure of birds to diets high in metals are known to have many adverse reproductive effects which include decreased egg production, decreased hatchability, and increased hatchling mortality (Scheuhammer 1987). It is for these reasons, screening of macrophytes growing in this wetlands for their phytoremediation potential has assumed importance and urgency. It is in this context, Ahmad et al. (2014, 2015) demonstrated that Phragmites australis, Potamogeton natans and Ceratophyllum demersum are good at accumulating high levels of heavy metals. It is in context of this that we focused on Typha angustata, an ideal choice for phytoremediation studies in view of its wide spread occurrence, high abundance across the world's wetlands, its broad tolerance to varied environmental conditions and different types of pollution, and its role in providing breeding ground and feeding material for a large number of avifaunal species. 


\section{Materials And Methods}

\section{Study Area}

Hokersar wetland $\left(34^{\circ} 06^{\prime} \mathrm{N}\right.$ latitude, $74^{\circ} 05^{\prime} \mathrm{E}$ longitude) is a perennial, protected wildlife reserve and a Ramsar site at an altitude of 1,584 m (amsl) lying about $12 \mathrm{kms}$ towards the northwest of Srinagar city in Kashmir Himalaya, India. Once spread over an area of $19.5 \mathrm{~km}^{2}$, the wetland has presently shrunk to just $13.26 \mathrm{~km}^{2}$. The wetland is fed by three inlts: Doodhganga, Dharmuna and Soyibugh streams. The water leaves the wetland through needle weir gate at Soziath village in the western side. Hokersar wetland is a paradise for myriad of migratory and residential avifaunal species and harbors about two million migratory waterfowl during winter that migrate from Central Asia, China, N-Europe and Siberia (Habib 2014). In addition to the geological weathering, anthropogenic activities such as municipal wastes and use of pesticides in the adjoining rice fields are an important source of heavy metals into the wetland. The practice of hunting/poaching of birds in the wetland by gun shots is also considered a source of heavy metals, particularly lead, to the wetland.

\section{Study Species}

Typha angustata L. (lesser bulrush) belongs to the family Typhaceae. It is an erect, perennial freshwater herb that can grow more than 3 meters in height. Its linear leaves are thick, ribbon-like structures which have a spongy cross-section exhibiting air channels (aerenchyma). The subterranean stem arises from thick creeping rhizomes (Motivans and Apfelbaum 1987). The plant tissues can store relatively high concentrations of some metals. T. angustata appears to have an internal copper and nickel tolerance mechanism. It is not likely that there is an evolutionary selection for heavy metal tolerance, but rather it is inherent in the species (Demirezen and Aksoy 2004).

\section{Chemical Analysis}

Water samples $(50 \mathrm{~mL})$ were digested with $2 \mathrm{M} \mathrm{HNO}_{3}$ at $95^{\circ} \mathrm{C}$ for $2 \mathrm{~h}$ and were made up to $100 \mathrm{ml}$ in volumetric flask with demineralized water. The digestion was done in glassware previously soaked in nitric acid and washed with demineralized water. The digested samples were analyzed for metals in duplicate using AAS Perkin Elmer, model Analyst 800. Sample blanks were also analyzed to correct for any contamination in the course of analysis. The plant samples were washed with distilled water in the laboratory. Shoot (leaves and stalks) and root tissues were separated and oven dried at $60^{\circ} \mathrm{C}$ to constant weight. The dried samples were weighed and ground to pass a 40 mesh screen using a Wiley mill. The plant analysis was carried out by acid digestion of dry samples of ground plant samples with a di-acid mixture (9 parts nitric acid: 4 parts perchloric acid) at about $80^{\circ} \mathrm{C}$. The digested samples were analyzed for ten metals (Al, $\mathrm{Cd}, \mathrm{Co}, \mathrm{Cr}, \mathrm{Cu}, \mathrm{Fe}, \mathrm{Mn}, \mathrm{Ni}, \mathrm{Pb}$ and $\mathrm{Zn}$ ) using AAS Perkin Elmer, model Analyst 800 .

\section{Data Analysis}


The mean and standard error of mean of metal concentrations in aboveground and belowground parts were calculated. Translocation factor which is a ratio of the concentration of metals $(\mu \mathrm{g} / \mathrm{g})$ in the plant shoot and leaves to that of the metals in root $(\mu \mathrm{g} / \mathrm{g})$ was also evaluated while the enrichment factor measuring the degree of enrichment and the transfer of metals into the plant sample by the water was evaluated by the ratio of the metal in the plant $(\mu \mathrm{g} / \mathrm{g})$ to the metal in the water $(\mathrm{mg} / \mathrm{L})$.

\section{Results And Discussion}

The concentration of heavy metals in roots and shoots of Typha angustata and in the water collected from the Hokersar wetland of Kashmir Himalaya are presented in Table 1. Fe and Al had the highest concentration in both roots and shoots. Mn was next in abundance to these two metals. The accumulation of different elements in roots and shoots of $T$. angustata was in order of $\mathrm{Fe}>\mathrm{Al}>\mathrm{Mn}>\mathrm{Cu}>\mathrm{Pb}>\mathrm{Co}>\mathrm{Cr}>\mathrm{Ni}>\mathrm{Cd}$. The percentage concentration of all the metals, except $\mathrm{Cr}, \mathrm{Pb}$ and $\mathrm{Zn}$ was more in roots than in shoots (Table 2). The concentration of different metals in water was in the following order: $\mathrm{Fe}>\mathrm{Al}>\mathrm{Mn}>\mathrm{Pb}>\mathrm{Cu}>\mathrm{Cr}>\mathrm{Zn}>\mathrm{Ni}>\mathrm{Co}>\mathrm{Cd}$.

Hyperaccumulators are characterized on the basis of different criteria which include: metal concentration in the shoots (Baker and Brooks 1989; Srivastava et al. 2006), translocation property (i.e., metal concentrations in the shoots should be higher than that in the roots, enrichment property evaluated as enrichment factor (Wei et al. 2006), and tolerance potential. According to Baker and Brooks (1989) and Srivastava et al. (2006) hyperaccumulators should have concentrations of $10000 \mu \mathrm{g} / \mathrm{g}$ for $\mathrm{Zn}$ and Mn; above $1000 \mu \mathrm{g} / \mathrm{g}$ dry mass for $\mathrm{Pb}, \mathrm{Cu}, \mathrm{Ni}$ and $\mathrm{Co}$; and $100 \mu \mathrm{g} / \mathrm{g}$ for $\mathrm{Cd}$. Concentrations of the metals investigated in $T$. angustata were lower than the aforementioned values, indicating that it is an accumulator rather than a hyperaccumulator. The lower values obtained for the metal concentrations than those characteristic of hyperaccumulators are related to the degree of contamination of this site and other related factors. Although shoot concentration of metals depends on the increase in the metal concentration in the habitat, accumulators display consistently lower levels than hyperaccumulators. Accumulators do not exceed the shoot concentrations described above (Baker and Brooks 1989; Zhou et al. 2006).

\section{Enrichment Factor}

The enrichment factor (EF) means the degree of metal transfer from the water to the plant roots and shoots. The higher enrichment factor for different metals in the roots than shoots of T. angustata (Table 2) for the 10 metals investigated during the present study indicates that the metals are accumulated in the roots. It is pertinent to mention that in order to be a better phytoremediation plant, the Enrichment Factor (EF) must be greater than 1. In T. angustata the least Enrichment Factor (EF) is 30 (Table 2) which corresponded to Al metal transfer to the plant root. The highest enrichment factor is shown by Co followed by Fe and Cd. This shows that Co is the most transferred metal to the root followed by Fe and $\mathrm{Cd}$ in decreasing order. The accumulation of $\mathrm{Co}$ by the plant indicates potential usefulness of $T$. angustata in cleaning up the wetland of this metal. Mechanisms of carcinogenicity have been discussed 
for metals, and beryllium, cadmium, chromium, cobalt, lead, nickel are some metals and metalloids that are carcinogenic to humans. The abnormalities noted when iron overdoses occur are dehydration, hypovolemia, anemia, evidence of hepatic necrosis (elevated alanine transaminase and aspartate transaminase activities), and liver failure (hypoglycemia, hyper-ammonemia) (Greentree and Hall 1995; Hillman 1995). Cd when ingested accumulates in kidneys. Cd is associated with induction of hypertension, cirrhosis of the liver, etc. (Higgins and Burns 1975). The prevalence of hypertension has been correlated with renal Cd in various geographic areas of the world (Schroeder et al. 1973). The International Agency for Research on Cancer (IARC) has classified cadmium as a human carcinogen (group I) on the basis of sufficient evidence in both humans and experimental animals. According to the observed results of EF for the investigated metals, it is apparent that T. angustata could be used for remediation of these metals.

\section{Translocation Factor and Heavy Metals Tolerance}

Another important feature of the plants used for phytoremediation is the translocation of metals from root to the plant shoot. Translocation factor (TF) assesses the transfer of accumulated metals from root to the plant shoot. The translocation factor of $T$. angustata is presented in Table 2 which shows a translocation factor $>1$ for $\mathrm{Zn}, \mathrm{Cr}$, and $\mathrm{Pb}$ while $\mathrm{TF} \leq 1$ for $\mathrm{Ni}, \mathrm{Cd}, \mathrm{Zn}, \mathrm{Cu}, \mathrm{Co}, \mathrm{Pb}, \mathrm{Fe}, \mathrm{Mn}$, and Al. To be considered a hyperaccumulator the translocation factor should be greater than one. Higher translocation factor for $\mathrm{Zn}, \mathrm{Cr}$, and $\mathrm{Pb}$ in $T$. angustata suggests significant translocation of these metals from roots to shoots. This indicates phytoremediation capability of $T$. angustata for these three metals. The translocation factor for the other metals indicates retention of these metals in the roots of $T$. angustata. In the present study $T$. angustata retained $90.41 \% \mathrm{Co}, 89.33 \% \mathrm{Al}$ and $81.39 \% \mathrm{Mn}$ in its belowground parts (Table 2). Guilizoni (1991) stated that aquatic macrophytes with a well-developed root rhizome system and totally submerged foliage extract elements mostly from sediments. Uptake by leaves becomes important when the metal concentrations in the surroundings are high. He further stated that division of labor between uptake of roots and shoots is probably associated with the anatomy and morphology of different taxa as well as with the sorptive capacities that are characteristic of species differing in growth rate, surface to volume ratio, and physiological condition of individual plants.

Hyperaccumulators should also have high tolerance to toxic contaminants which is true of $T$. angustata as revealed by the present study. Such an observation draws support from the work of Demirezen and Aksoy (2004) who also reported that the tissues of $T$. angustata accumulate more heavy metals than the tissues of Potamogeton pectinatus. It was also suggested that the short life cycle of $T$. angustata is the main reason for it being able to sequester more metals in roots than in the shoots. According to Bareen and Khilji (2008) plants that hyperaccumulate metals have a tremendous potential for application in remediation of metals in the environment and $T$. angustata is one such hydrophyte with good hyper accumulation capabilities. Burada et al. (2015) reported that $T$. angustata has a greater bioaccumulation capability than Phragmites australis, Potamogeton pectinatus and Stratiotes aloides. Rai et al (2008) stated that Typha is a potent plant for heavy metal removal along with, Phragmites, Eichhornia, Azolla, and Lemna. Chandra and Yadav (2010) also concluded that $T$. 
angustifolia could be a potential phytoremediator for heavy metals. Yen and Saibeh (2013) showed that T. angustifolia was a metal excluder plant species when grown in mine water effluence at ex-Mamut copper mine, Ranau. It accumulated high amount of Fe in the roots but low concentration in aboveground tissues. It could use for phytostabilisation which very useful in revegetation plan for high toxicity areas such as stagnant water areas and bench of the pit. Thus the present study suggests that the $T$. angustata is a good hyperaccumulator of $\mathrm{Zn}, \mathrm{Cr}$ and $\mathrm{Pb}$ while it serves as an accumulator of $\mathrm{Fe}, \mathrm{Al}, \mathrm{Mn}$, $\mathrm{Zn}, \mathrm{Cu}, \mathrm{Cd}, \mathrm{Co}$ and Nid for phytostabilization in revegetation plans for high toxicity areas such as stagnant water areas.

\section{Conclusion}

Our study suggests that the $T$. angustata is a hyperaccumulator of $\mathrm{Zn}, \mathrm{Cr}$ and $\mathrm{Pb}$ while it serves as an accumulator of $\mathrm{Fe}, \mathrm{Al}, \mathrm{Mn}, \mathrm{Zn}, \mathrm{Cu}, \mathrm{Cd}, \mathrm{Co}$. and $\mathrm{Ni}$. These metals are retained in the belowground parts of the study species suggesting that an exclusion strategy for metal tolerance exists in this species. Thus the results obtained in the present study and substantiated by earlier works reveal $T$. angustata can be used for removal of heavy metal from polluted wetlands. Moreover, the higher retention of heavy metals in the belowground parts of the $T$. angustata reduces their transmission to avifauna, which mainly feed on aboveground parts of this plant, thereby preventing bioaccumulation of heavy metals in higher trophic levels. This further adds to the desirability of $T$ angustata as a potential phytoremediation species. Being a potent phytoremediation plant it can be used an efficient hyperaccumulator for the removal of different heavy metals from the contaminated sites. Moreover, the plant can be easily inoculated in constructed wetlands for the removal of heavy metals particularly $\mathrm{Zn}, \mathrm{Cr}$ and $\mathrm{Pb}$.

\section{Declarations}

\section{ACKNOWLEDGEMENTS}

We are thankful to Head, Department of Botany, University of Kashmir, J\&K, India, for providing necessary facilities during the course of this study.

Funding we are thankful to UGC for providing the funding to carry out the research.

Conflicts of interest/Competing interests there is no conflict of interest in this piece of research.

Availability of data and material the data presented in this paper is the original data collected during the research.

Code availability different statistical analysis was carried out using MS Excel.

Ethics approval proper research ethics were followed to carry out the research and for its publication.

Consent to participate the different coauthors participated in completing the research. 
Consent for publication we give the consent for publication of this original research in Archives of Environmental Contamination and Toxicology.

\section{References}

Ahmad SS, Reshi ZA, Shah MA, Rashid I, Ara R, Andrabi SMA (2014) Phytoremediation potential of Phragmites australis in Hokersar wetland- A Ramsar site of Kashmir Himalaya. Int J Phytorem 16: 11831191

Ahmad SS, Reshi, ZA, Shah MA, Rashid I, Ara R, Andrabi SMA (2015) Heavy metal accumulation by Potamogeton natans and Ceratophyllum demersum in a Himalayan RAMSAR site: management implications. Wetlands Ecol Manage DOI 10.1007/s11273-015-9472-9

American Public Health Association (APHA) (1998) Standard Methods for Examination of Water and Wastewater.20th ed. American Public Health Association, Washington, DC, USA

Baker AJM, Brooks RR (1989) Terrestrial higher plants which hyperaccumulate metallic elements - a review of their distribution, ecology and phytochemistry. Biorecovery 1: 81-126

Bareen F, Khilji S (2008) Bioaccumulation of metals from tannery sludge by Typha angustifolia L Afr J Biotechnol 18: 3314-3320

Buruiana DL, Lefter D, Tiron GL, Balta S, Bordei M (2015) Toxicity of heavy metals on the environment and human health. 15th International Multidisciplinary Scientific Geo Conference SGEM 2015, www.sgem.org, SGEM2015 Conference Proceedings, ISBN 978-619-7105-40-7 / ISSN 1314-2704 Book5 Vol. 2: 565-572 pp

Chandra R, Yadav S (2011) Phytoremediation of $\mathrm{Cd}, \mathrm{Cr}, \mathrm{Cu}, \mathrm{Mn}, \mathrm{Fe}, \mathrm{Ni}, \mathrm{Pb}$ and $\mathrm{Zn}$ from Aqueous Solution using Phragmites cummunis, Typha angustifolia and Cyperus esculentus. Int J Phytorem 13: 580-591

Chandra R, Yadav S (2010) Potential of Typha angustifolia for phytoremediation of heavy metals from aqueous solution of phenol and melanoidin. Ecol Eng 36(10): 1277-1284

Choppala G, Saifullah Bolan N, Bibi S, lqbal M, Rengel Z, Kunhikrishnan A, Ashwath N, Ok YS (2014) Cellular Mechanisms in Higher Plants Governing Tolerance to Cadmium Toxicity. Cr Rev Plant Sci 33: 374-391

Demirezen D, Aksoy A (2004) Accumulation of heavy metals in Typha angustifolia (L.) and Potamogeton pectinatus (L.) living in Sultan Marsh (Kayseri, Turkey). Chemosphere 56: 685-696

Deng H, Ye ZH, Wong MH (2004) Accumulation of lead, zinc, copper and cadmium by 12 wetland plants species thriving in metal contaminated sites in China. Environ Pollut 132: 29-40 
Gerhardt KE, Huang XD, Glick BR, Greenberg BM (2009) Phytoremediation and rhizoremediation of organic soil contaminants: Potential and challenges Plant Sci 2009; 176: 20-30

Greentree WF, Hall JO (1995). Iron toxicosis. In: Bonagura JD, ed. Kirk's current therapy XII small animal practice. Philadelphia, Pa: WB Saunders Co, 240-242

Gullizzoni P (1991) The role of heavy metals and toxic materials in the physiological ecology of submerged macrophytes. Aquat Bot 41: 87-109

Habib M (2014) Bird community structure and factors affecting the avifauna of Hokersar wetland Kashmir. Int J Curr Res 6(7): 7397-7403

Haggins IJ, Burns RG (1975) The chemistry and microbiology of pollution. Academic Press. New York. pp 248

Hillman RS. (1995) Hematopoietic agents: growth factors, minerals, and vitamins. In: Hardman JG, Limbird LE, Molinoff PB, et al, eds. Goodman \& Gilman's the pharmacological basis of therapeutics. 9th ed. New York City, NY: McGraw-Hill: 1311-1340

Hu J, Zheng A, Pei D, Shi G (2010) Bioaccumulation and chemical forms of cadmium, copper and lead in aquatic plants. Braz Arch Biol Technol 53:235-240

Kramer U (2010) Metal hyperaccumulation in plants. Annu Rev Plant Biol 61: 517-534

Kramer, U. 2010. Metal hyperaccumulation in plants. Annual Reviews of Plant Biology 61: 517-534.

Mishra VK, Upadhaya AR, Pandey SK, Tripathy BD (2007) Concentration of heavy metals in aquatic macrophytes from two small rivers polluted by urban, agricultural, and textile industry sewages $\mathrm{SW}$ Poland. Arch Environ Contam Toxicol 53, 198-206

Motivans K, Apfelbaum S (1987) The nature conservancy element stewardship abstract, Typha ssp. $\mathrm{V}_{11}$. Document preparation and maintenance. Applied Ecological Services, Inc Juda WI 53550 608/897-8547

Nies DH (1999) Microbial heavy-metal resistance. Appl Microbiol Biotechnol 5, 1730-750

Qian JH, Zayed A, Zhu YL, Yu M, Terry N (1999) Phytoremediation of trace elements by wetland plants: III. Uptake and accumulation of ten trace elements by twelve plant species. J Environ Qual 28: 1448-1455

Rai PK (2008) Heavy metal pollution in aquatic ecosystems and its phytoremediation using wetland plants: an ecosustainable approach. Int J Phytoremed 10 (2): 133-160

Rai UN, Sinha S, Tripathy RD, Chandra P (1995) Wastewater treatability potential of some aquatic macrophytes: removal of heavy metals. Ecol Eng 5: 5-12 
Samecka-Cymerman A, Kempers AJ (2003) Biomonitoring of water pollution with Elodea Canadensis. A case study of three small Polish rivers with different levels of pollution. Water Air Soil pollut 145 139-153

Sanchez ML (2008) (ed.). Causes and Effects of Heavy Metal Pollution, p. 392. Nova Science Publishers, Hauppauge

Scheuhammer AM (1987) The chronic toxicity of Aluminium, Cadmium, Mercury, and Lead in Birds: A Review. Environ Pollut 46: 263-295

Schroeder DC, Lee FG (1975) Potential transformations of chromium in natural waters. Water Air Soil Pollut 4: 461-463

Sharma SS, Gaur JP. (1995) Potential of Lemna polyrhiza for removal of heavy metals. Ecol Eng 4: 37-45

Srivastava M, Ma LQ, Santos JAG (2006) Three new arsenic hyperaccumulating ferns. Sci Total Environ 364: 24-31

Szymanowska A, Samecka-Cymerman A, Kampers AJ (1999) Heavy metals in three lakes of Poland. Ecotoxicol Environ Saf 43: 21-29

Vardanyan LG, Ingole BS (2006) Studies on heavy metal accumulation in aquatic macrophytes from Sevan (Armenia) and Carambolim (India) lake systems. Environ Int 32: 208-218

Wei SH, Zhou QX, Koval PV (2006) Flowering stage characteristics of cadmium hyperaccumulator Solanum nigrum L. and their significance to phytoremediation. Sci Total Environ 369: 441-446

Yen LV, Saibeh K (2013) Phytoremediation using Typha angustifolia L. for mine water effluence treatment: case study of ex-mamut copper mine, Ranau, Sabah Borneo. Science 33: 16

Zhang M, Cui L, Sheng L, Wang Y (2009) Distribution and enrichment of heavy metals among sediments, water body and plants in Hengshuihu wetland of Northern China. Ecol Eng 35: 563-569

Zhou QX, Wei SH, Zhang QR (2006) Ecological Remediation. Chinese Environmental Science Press, Beiging, China

\section{Tables}

Table 1. Metal contents in plant parts $(\mathrm{mg} / \mathrm{kg})$ and water samples $(\mathrm{mg} / \mathrm{l})$. 


\begin{tabular}{|c|c|c|c|}
\hline \multicolumn{4}{|c|}{ Heavy metal } \\
\hline & \multicolumn{2}{|c|}{ Concentration $(\mathrm{mg} / \mathrm{Kg})$} & \multirow{2}{*}{$\begin{array}{l}\text { Concentration in water } \\
\text { (mg/litre) }\end{array}$} \\
\hline & Root & Shoot & \\
\hline $\mathrm{Cr}$ & $9.12 \pm 0.89$ & $2.79 \pm 0.09$ & $0.025 \pm 0.00$ \\
\hline Co & $16.01 \pm 0.48$ & $150.9 \pm 3.30$ & $0.01 \pm 0.00$ \\
\hline $\mathrm{Pb}$ & $30.4 \pm 1.83$ & $24.95 \pm 5.83$ & $0.062 \pm 0.00$ \\
\hline $\mathrm{Zn}$ & $5.80 \pm 0.90$ & $5.80 \pm 0.90$ & $0.06 \pm 0.00$ \\
\hline $\mathrm{Cu}$ & $9.294 \pm 1.25$ & $9.57 \pm 0.34$ & $0.30 \pm 0.01$ \\
\hline $\mathrm{Al}$ & $236 \pm 10.28$ & $1976.4 \pm 35.11$ & $7.85 \pm 0.78$ \\
\hline $\mathrm{Cd}$ & $2.62 \pm 0.11$ & $3.08 \pm 0.57$ & $0.004 \pm 0.00$ \\
\hline $\mathrm{Ni}$ & $2.20 \pm 0.05$ & $4.88 \pm 0.54$ & $0.03 \pm 0.08$ \\
\hline $\mathrm{Mn}$ & $75.4 \pm 10.59$ & $329.86 \pm 3.19$ & $0.67 \pm 0.06$ \\
\hline $\mathrm{Fe}$ & $4316 \pm 407.29$ & $15845 \pm 279.30$ & $5.85 \pm 1.06$ \\
\hline
\end{tabular}

Table 2. Percentage concentration, translocation factor and enrichment factors of metals from water to root and shoot of Typha angustifolia.

\begin{tabular}{|c|c|c|c|c|c|}
\hline \multirow[t]{2}{*}{ Heavy metal } & \multicolumn{2}{|c|}{ Percentage concentration } & \multicolumn{2}{|c|}{ Enrichment factor } & \multirow[b]{2}{*}{ Translocation facto } \\
\hline & Shoot & Root & Shoot & Root & \\
\hline $\mathrm{Cr}$ & $76.57 \%$ & $23.43 \%$ & 112 & 365 & 3.3 \\
\hline Co & $9.59 \%$ & $90.41 \%$ & 15090 & 1601 & 0.1 \\
\hline $\mathrm{Pb}$ & $54.92 \%$ & $45.08 \%$ & 402 & 490 & 1.2 \\
\hline $\mathrm{Zn}$ & $50.00 \%$ & $50.00 \%$ & 97 & 333 & 3.4 \\
\hline $\mathrm{Cu}$ & $49.27 \%$ & $50.73 \%$ & 32 & 31 & 1.0 \\
\hline $\mathrm{Al}$ & $10.67 \%$ & $89.33 \%$ & 252 & 30 & 0.1 \\
\hline $\mathrm{Cd}$ & $45.96 \%$ & $54.04 \%$ & 770 & 655 & 0.9 \\
\hline $\mathrm{Ni}$ & $31.07 \%$ & $68.93 \%$ & 163 & 73 & 0.5 \\
\hline $\mathrm{Mn}$ & $18.61 \%$ & $81.39 \%$ & 492 & 113 & 0.2 \\
\hline $\mathrm{Fe}$ & $21.41 \%$ & $78.59 \%$ & 2709 & 738 & 0.3 \\
\hline
\end{tabular}

